\title{
ESTE FILME O BRASIL JÁ VIU
}

Marcos Vinicio Jorge de Freitas*

Há quase 140 anos - mais precisamente em 1855 - ocorreu a última execução no Brasil. Um fazendeiro fluminense foi executado pela suposta chacina da família de sua jovem amante. Descobertos os culpados após a execução, houve tamanha comoção que o Imperador passou daí em diante a comutar todas as penas para galés perpétuas, pena hoje folclórica e motivo de blagues em comédias cinematográficas dos anos 20, não tão divertida assim para os condenados, obrigados a usar grossas correntes nos pés, ou com pesos ou ligando a outro sentenciado, enquanto realizavam trabalhos públicos.

A pena de morte só foi formalmente abolida em 1890, com a promulgação de novo Código Penal, já na República.

Mas pode-se dizer que a pena de morte no Brasil teve dois momentos: um antes da outorga da Constituição de $1824 e$ outro depois. Estes diferentes momentos envolvem não só a independência de Portugal, mas toda uma nova postura filosófica frente aos delitos e às penas, postura essa cristalizada pelo jurista italiano Cesare Beccaria, em sua célebre obra "Dos Delitos e das Penas", de 1764.

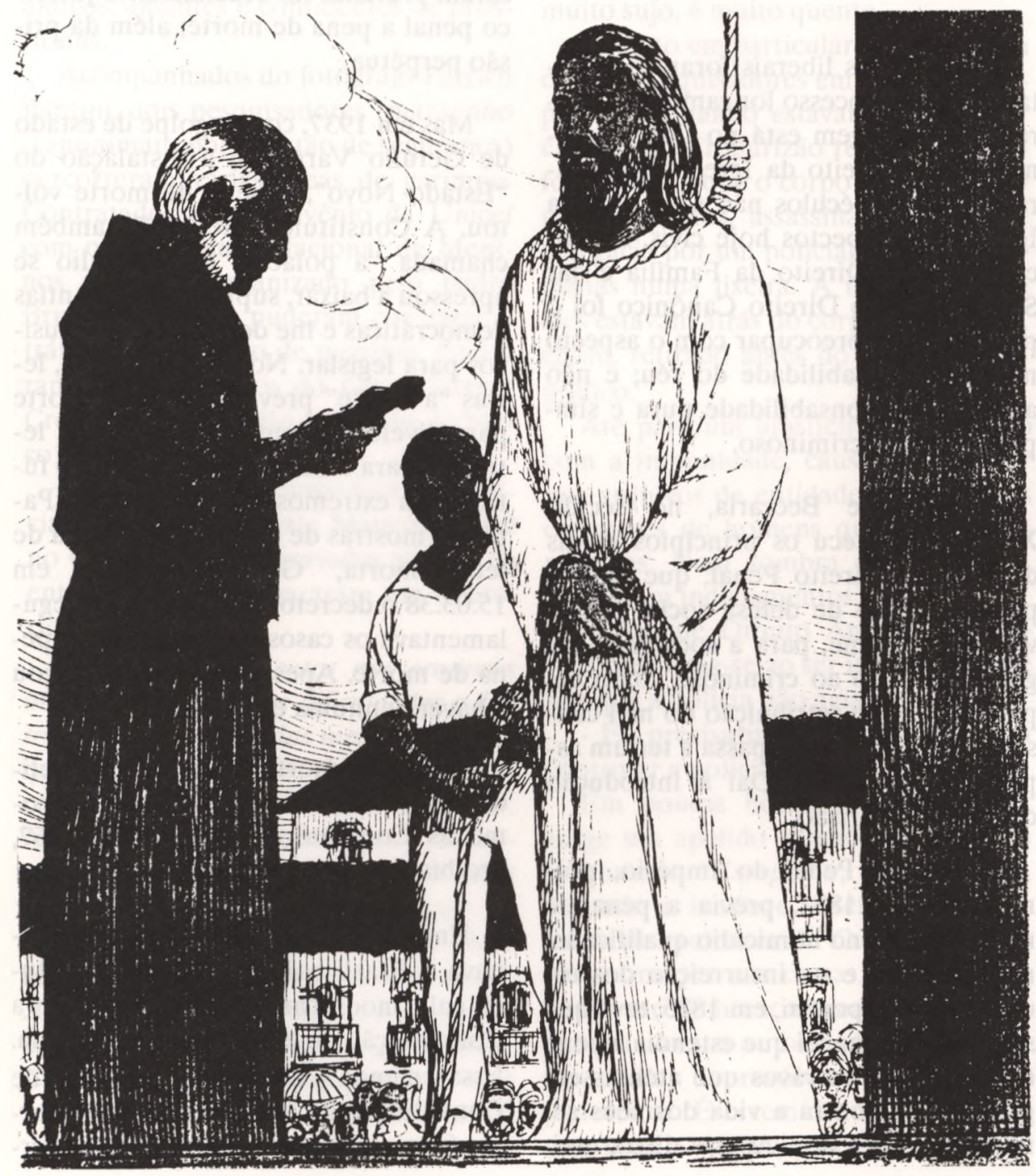

\section{A MORTE NATURAL PARA SEMPRE}

A partir do século XVI, na Europa, a pena de morte conheceu um trágico apogeu. Instrumento dos reis para a afirmação da centralização política e administrativa, era motivo de orgulho para os juízes que as aplicassem aos milhares. Pena Antiqüíssima, aplicada desde tempos imemoriais, foi progressivamente monopolizada pelo Estado, com o fim, por exemplo, em Roma, na literal execução do devedor para cobrança de dívidas.

Mas a morte não era a pena e ponto final. A cada crime correspondia um tipo diferente de execução, que também variava segundo a condição social do réu. (Nesse sentido, a Revolução Francesa democratizou também a pena de morte, estendendo a decapitação - antes privilégio dos nobres - a todos.) Em Roma, como é bem sabido, havia a crucificação e a morte pelas feras no Coliseu. 
Na Idade Moderna não foi diferente. $\mathrm{O}$ crime de lesa-majestade era punido com a morte sob as mais bárbaras torturas que o sadismo do carrasco pudesse criar; os hereges eram mortos na fogueira; hereges arrependidos e falsificadores de moeda eram garroteados e em seguida queimados; a forca - considerada infamante - era reservada a outros falsificadores, aos adúlteros, aos feiticeiros, aos autores de homicídios dolosos e parricidas, entre outros. Já os assassinos profissionais e os escravos que matassem seu senhor tinham morte natural precedida do corte das duas mãos e atenazamento (aperto dos músculos). Tudo de acordo com as Ordenações Manuelinas e Filipinas que vigeram em Portugal, e, conseqüentemente, no Brasil. (É de se notar que as Ordenações Filipinas, de 1604, no que tange ao Direito Civil, vigeram no Brasil até 1916.)

E a tudo isso, podia ser acrescentado, pelo juiz, a "morte natural para sempre", em que o corpo do executado - ou supliciado - ficava no local da execução - quase sempre uma praça públi$\mathrm{ca}$ - até $1^{\circ}$ de Novembro, quando eram recolhidos para serem sepultados no dia dos Mortos.

Dessas penas, surge nítido que os crimes mais graves eram aqueles praticados contra o rei e a administração pública. Isso é compreensível numa época em que os súditos estavam sempre distantes do poder real, espalhados por espaços imensos, como o caso do Brasil. Às penas era preciso dar um caráter tão horrível que a impressão permanecesse para sempre na memória. Basta lembrar a execução de Tiradentes e o célebre quadro que a representa. Dificilmente alguém que tenha visto o quadro esquece o horror que provoca. (E no que toca à execução de Tiradentes, não custa lembrar que todos os outros em posição social melhor tiveram a pena de morta comutada para degredo.)

Vale lembrar, também, que o crime de heresia era um crime contra o Estado, e que a Inquisição foi instalada nos países ibéricos a pedido dos reis, preocupados com a unidade cultural e ideológica de uma nação recém-reconquistada aos mouros.

\section{O FIM DAS PENAS CRUÉIS}

A Constituição de 1824, imbuída em muitos aspectos dos ventos do Iluminismo e das Revoluções liberais, acabou com as penas cruéis. Mas não com a pena de morte. Apenas com os suplícios.

Porém, penas cruéis como o açoite e a marca com ferro quente continuaram a ser aplicadas aos escravos, considerados como algo entre um bem e um ser humano.

Esses ventos liberais foram o resultado de um processo longamente maturado, cuja origem está no Direito Canônico. O Direito da Igreja regeu durante muitos séculos não só a própria Igreja, mas aspectos hoje civis, ou laicos, como o Direito da Família e das Sucessões. E o Direito Canônico foi o primeiro a se preocupar com o aspecto moral da culpabilidade do réu; e não apenas a responsabilidade pura e simples pelo fato criminoso.

A obra de Beccaria, no século XVIII, estabelecu os princípios gerais desse novo Direito Penal, que dava à pena a função de defesa social e prevenção do crime, para a sociedade em geral; servindo ao criminoso como expiação moral e retribuição do mal causado. Ou seja, a pena passa a ter um aspecto regenerativo. Daí a introdução das penas de prisão.

O Código Penal do Império, promulgado em 1831, previa a pena de morte apenas no homicídio qualificado, no latrocínio e na insurreição dos escravos. Logo, porém, em 1835, teve que ser passada uma lei que estendia a pena de morte aos escravos que atentassem gravemente contra a vida dos seus senhores ou do feitor. Apesar disso, mui- tos princípios do Direito Penal atual, como a irretroatividade da lei penal, exceto para beneficiar o réu, a limitação dos efeitos da pena apenas ao condenado e o direito a um julgamento minimamente justo foram garantidos.

Além disso, a pena de morte não era aplicada a crimes políticos - excluída a insurreição de escravos - e, para ser aplicada, necessitava votação unânime do júri pela condenação.

\section{A ABOLIÇÃO CONSTITUCIONAL DA PENA DE MORTE}

Constituição de 1891 incluiu, pela primeira vez, a garantia à vida, excluindo das penas passíveis de serem previstas no ordenamento jurídico penal a pena de morte; além da prisão perpétua.

Mas em 1937, com o golpe de estado de Getúlio Vargas, e a instalação do "Estado Novo", a pena de morte voltou. A Constituição de 1937, também chamada "a polaca", que Getúlio se apressou a baixar, suprimiu as garantias democráticas e lhe deu poderes exclusivos para legislar. No seu artigo 172 , letras "a" e "e" previu a pena de morte para diversos crimes políticos e, na letra "f", para o homicídio por motivo fútil e com extremos de perversidade. Para dar mostras de que não se tratava de letra morta, Getúlio baixou, em 15.03.38 o decreto-lei $n^{\circ} 431$, que regulamentava os casos de aplicação da pena de morte. Apesar disso, não chegou a haver nenhuma execução.

A pena de morte voltaria a ser abolida pela Constituição de 1946 que, como as Constituições de 1934 e 1967, proibia a pena de morte.

Em 1969, a Junta Militar que governava o Brasil baixou emenda constitucional modificando radicalmente a Constituição de 1967 recém-outorgada. Essa emenda - que alguns chamam de Constituição de 1969, tamanha a reforma feita -, reintroduziu a pena de mor- 
te no $\S 11$ do artigo 150 , limitada aos casos de guerra externa, "guerra psicológica adversa, revolucionária ou subversiva".

Ato contínuo, foi baixado por decreto-lei uma nova Lei de Segurança Nacional, punindo com morte a tentativa de submissão do território nacional a outro país; a sabotagem de instalações militares, navios, aviões, vias de transporte, estaleiros, portos, aeroportos, fábricas; a violência contra Chefes de Governo estrangeiros em visita ao Brasil e embaixadores; a insurreição armada; os atentados políticos; entre outros crimes, que causassem a morte de alguém.

Essa Lei de Segurança Nacional vigorou no Brasil até fim dos anos 70, quando foi modificada no bojo da chamada "abertura política", promovida no final do governo Geisel.

\section{A PENA DE MORTE NO CÓDIGO PENAL MILITAR}

A Lei de Segurança Nacional de 1969 nada mais fazia que estender aos civis, em tempo de paz, punição com a morte para crimes militares em tempo de guerra.

A atual Constituição, na letra "a" do inciso XLVII do artigo $5^{\circ}$, estabelece que não haverá pena de morte, "salvo em caso de guerra declarada".

Declarada a guerra, passam a vigorar os dispositivos do Código Penal Militar, que prevêem pena de morte não só para os casos acima citados da antiga Lei de Segurança Nacional, mas para crimes como o de demonstrar medo diante dos soldados comandados.

Como se pôde notar, a pena de morte tem história no Brasil, e hoje, mais uma vez reacende-se o debate em torno da mesma.

* Marcos Vinicio Jorge de Freitas é Advogado, Historiador e Mestrando do PROLAM - Programa de Pós-Graduação em Integraçũo da América Latina da USP.

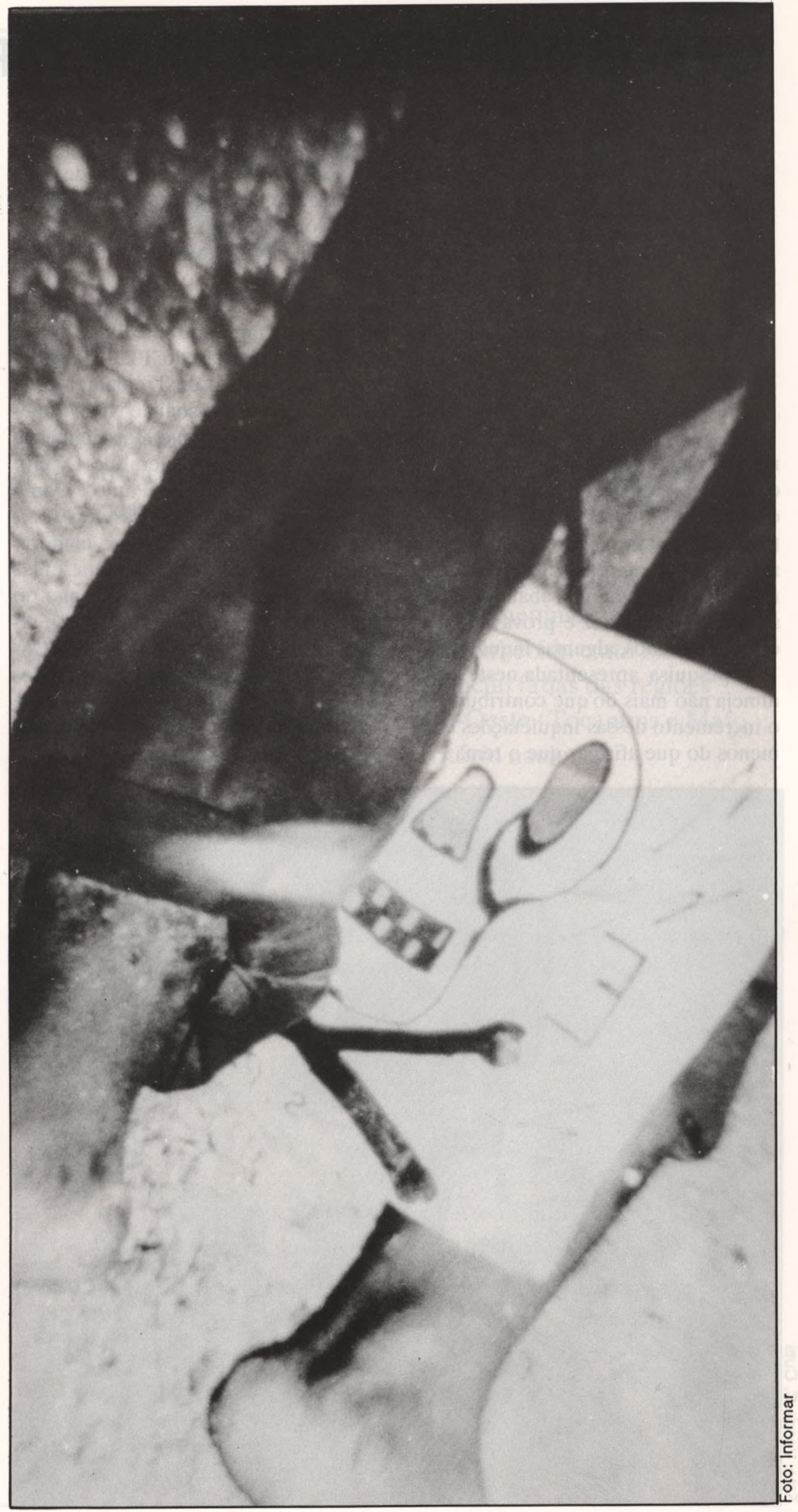

